\title{
Ujawnienie tajemnicy skarbowej na podstawie artykułu 299b Ordynacji podatkowej
}

\section{Disclosure of fiscal secrecy in the light of Article 299b of the Tax Ordinance Act}

Streszczenie. Artykuł poświęcony jest problematyce ujawniania przez organy podatkowe informacji stanowiących tajemnicę skarbową na gruncie art. 299b Ordynacji podatkowej. Autor wskazał, że zgoda Szefa Krajowej Administracji Skarbowej na ujawnienie przez naczelników urzędów skarbowych, naczelników urzędów celno-skarbowych, dyrektorów izb administracji skarbowej, określonych informacji stanowiących tajemnicę skarbową zapada w ramach uznania administracyjnego przy użyciu pojęć niedookreślonych (klauzul generalnych), co rodzi istotne niebezpieczeństwo z założenia generujące niejasności interpretacyjne. Ponadto, biorąc pod uwagę szeroki krąg podmiotów, które mogą występować z wnioskami do Szefa Krajowej Administracji Skarbowej o ujawnianie tajemnicy skarbowej, bez wątpienia analizowany przepis prawny wymaga bezzwłocznej „korekty”, ponieważ nie gwarantuje podatnikom właściwej ochrony ich praw. 
Słowa kluczowe: tajemnica skarbowa; organ podatkowy; organ skarbowy; Ordynacja podatkowa; Krajowa Administracja Skarbowa; Szef Krajowej Administracji Skarbowej.

\begin{abstract}
This paper addresses the subject matter of a disclosure of information constituting fiscal secrets made by tax authorities on the ground of Article 299b of the Tax Ordinance Act. The Author demonstrates that a Head of the National Revenue Administration gives his/her consent to the heads of tax offices, heads of customs and fiscal offices and directors of tax administration chambers to reveal certain information constituting fiscal secrets. This consent is given under administrative discretion by means of under-defined terms (general clauses). An act of the Head of the National Revenue Administration poses a significant risk, which in principle generates interpretation ambiguities. The analysed provision (without any doubts) requires immediate "correction” since it does not guarantee appropriate protection of tax-payers' rights owing to the broad range of entities who may request the Head of the National Revenue Administration to reveal a fiscal secret.
\end{abstract}

Keywords: fiscal secret; tax authority; fiscal authority; Tax Ordinance Act; National Revenue Administration; Head of the National Revenue Administration.

\title{
1. Uwagi wprowadzające
}

Założeniem niniejszej publikacji jest przedstawienie podstawowych problemów związanych z ujawnianiem przez organy podatkowe określonych informacji stanowiących tajemnicę skarbową w świetle przepisu art. 299b Ordynacji podatkowej $^{1} \mathrm{z}$ uwzględnieniem stanowisk prezentowanych przez doktrynę prawa podatkowego i judykaturę, na pragmatyce organów administracji publicznej kończąc wraz postulatami de lege lata i de lege ferenda. W tym celu zaprezentowane wywody koncentrują się co do zasady wokół zakresu obowiązywania tajemnicy skarbowej oraz zgody Szefa Krajowej Administracji Skarbowej jako warunku sine qua non jej ujawnienia wraz z przesłankami unormowanymi w art. 299b § 1-2 o.p.

1 Ustawa z dnia 29 sierpnia 1997 r. Ordynacja podatkowa (tekst jedn. Dz.U. z 2020 r., poz. 1325 ze zm.), dalej: o.p. 
Wykładnia przepisu art. 299b o.p. już od momentu jego uchwalenia rodzi liczne spory interpretacyjne, nie tylko uczestników stosunków podatkowoprawnych, ale także wśród przedstawicieli środowiska naukowego. Tym samym, biorąc pod uwagę niedostatki obecnej regulacji prawnej, podjęte w opracowaniu rozważania uzasadniają postawienie tezy, że w tej kwestii ustawa Ordynacja podatkowa wymaga nowelizacji m.in. z powodu przesłanek z art. 299b o.p. mających charakter pojęć niedookreślonych (klauzul generalnych) i dających Szefowi Krajowej Administracji Skarbowej możliwość nieograniczonej swobody w podejmowaniu „rozstrzygnięć” w zakresie wyrażania zgody na ujawnienie informacji objętych tajemnicą skarbową, oczywiście ze szkodą dla biernych podmiotów stosunków podatkowoprawnych.

\section{Tajemnica skarbowa}

\section{- zakres obowiązywania}

Ustawodawca na gruncie prawa podatkowego nie sformułował definicji legalnej tajemnicy skarbowej, określając jedynie expressis verbis jej zakres przedmiotowy i podmiotowy ${ }^{2}$ (tzw. zakresowa definicja tajemnicy skarbowej) w przepisach art. 293-294 o.p. ${ }^{3}$

Artykuł 293 § 1 o.p. - normujący zakres przedmiotowy tajemnicy skarbowej - dotyczy indywidualnych danych zawartych w deklaracjach oraz innych dokumentach składanych przez podatników, płatników lub inkasentów. Ponadto przepis § 1 art. 293 o.p. stosuje się również do danych zawartych w: informacjach podatkowych przekazywanych organom podatkowym przez podmioty inne niż wymienione w $\S 1$ art. 293 o.p.;

2 Według J. Glinieckiej tajemnica skarbowa „realizuje te same założenia, które przewidziano dla instytucji tajemnicy bankowej” - J. Gliniecka, Komentarz do art. 293 o.p. [w:] H. Dzwonkowski (red.) Ordynacja podatkowa. Komentarz, Legalis/el. 2011; taż Tajemnica finansowa. Aspekty aksjologiczne, normatywne i funkcjonalne, BydgoszczGdańsk 2007, s. 122; zob. także S. Banasiak, D. Oraczewska, Tajemnica skarbowa a tajemnica bankowa, Warszawa 1998; M. Kośmider, Gromadzenie przez organy podatkowe informacji objętych tajemnicq bankowq a prawo do prywatności, „Kwartalnik Prawa Podatkowego" 2002, nr 1, s. 45-63.

3 Wyrok NSA z dnia 18 listopada 2016 r., I FSK 672/15, CBOSA. 
aktach dokumentujących czynności sprawdzające; aktach postępowania podatkowego, kontroli podatkowej, kontroli celno-skarbowej oraz aktach postępowania w sprawach o przestępstwa skarbowe lub wykroczenia skarbowe; dokumentacji rachunkowej organu podatkowego; informacjach uzyskanych przez organy Krajowej Administracji Skarbowej z banków oraz z innych źródeł niż wymienione w § 1 lub w pkt 1 § 2 art. 293 o.p.; informacjach uzyskanych w toku procedur rozstrzygania sporów dotyczących podwójnego opodatkowania oraz $\mathrm{w}$ toku postępowania w sprawie wydania uprzednich porozumień cenowych, o których mowa w ustawie z dnia 16 października 2019 r. o rozstrzyganiu sporów dotyczących podwójnego opodatkowania oraz zawieraniu uprzednich porozumień cenowych; aktach dokumentujących kontrolę, o której mowa w rozdziale 9 działu III ustawy z dnia 9 marca 2017 r. o wymianie informacji podatkowych z innymi państwami; informacjach o wynikach analizy ryzyka, o której mowa w art. 119zn $\S 1$ o.p. oraz innych informacjach i dokumentach, o których mowa w dziale IIIB o.p.; informacjach i dokumentach, o których mowa w dziale III w rozdziale 11a o.p.; aktach postępowania w sprawie wydania opinii zabezpieczającej oraz aktach postępowania określonego w dziale IIIA w rozdziale 5 o.p.; informacjach o ustaleniu prawdopodobieństwa wystąpienia opóźnień, o których mowa w art. $299 f$ o.p.; informacjach przekazanych przez podatnika $\mathrm{w}$ ramach realizacji współdziałania, o którym mowa w dziale IIB o.p. ${ }^{4}$

Bez wątpienia dokonana przez ustawodawcę w sposób bardzo szeroki kazuistyczna regulacja zakresu przedmiotowego tajemnicy skarbowej jest następstwem zasady powszechności obowiązku podatkowego ${ }^{5}$ oraz stosunku podatkowoprawnego opartego na nierównorzędności jego podmiotów i pojawieniu się władztwa organu administracji publicznej ${ }^{6}$.

4 W. Stachurski, Komentarz do art. 293 o.p. [w:] L. Etel (red.), Ordynacja podatkowa. Komentarz aktualizowany, LEX/el. 2020; zob. także pismo Ministra Finansów z dnia 26 marca 1998 r., nr FB 1/235/Ch/98, LEX/el.

5 J. Gliniecka, H. Dzwonkowski, J. Kondratowska, Komentarz do art. 293 o.p. [w:] H. Dzwonkowski (red.), Ordynacja podatkowa. Komentarz, Legalis/el. 2014.

6 I. Nowak, Wyłączenie samorzq̨dowych organów podatkowych od załatwiania spraw w postępowaniu podatkowym, „Przegląd Podatków Lokalnych i Finansów Samorządowych” 2017, nr 6, s. 20-26; tenże, Ciężar dowodzenia w postępowaniu podatkowym 
Oznacza to, że inkwizycyjność stosunku podatkowoprawnego ${ }^{7}$, powodowana ingerencyjnością prawa podatkowego ${ }^{8}$, wymaga ochrony podatnika jako podmiotu słabszego ${ }^{9}$ i w tym też celu prawodawca, dążąc do zagwarantowania minimalnej równowagi, wprowadził m.in. mającą charakter normatywny zasadę ogólną postępowania podatkowego ${ }^{10}$ - jawności procedury podatkowej wyłącznie dla stron tego procesu (art. 129 o.p.) ${ }^{11}$ a na tajemnicy skarbowej kończąc ${ }^{12}$.

Podsumowując przedstawione powyżej rozważania, należy dojść do wniosku, że wszystkie informacje wskazane w przepisie art. 293 § 1-2 o.p. objęte są tajemnicą skarbową ${ }^{13}$ jako kwalifikowany rodzaj tajemnicy

- podstawowe problemy [w:] B. Kucia-Guściora, M. Münnich, A. Zdunek, R. Zieliński (red.), Stanowienie i stosowanie prawa podatkowego w Polsce. Ocena i kierunki zmian, Lublin 2016, s. 183 i n.; wyrok WSA w Gliwicach z dnia 16 stycznia 2009 r., III SA/Gl 305/08, CBOSA; wyrok WSA w Poznaniu z dnia 23 lipca 2015 r., I SA/Po $124 / 15$, CBOSA.

7 Wyrok WSA w Gliwicach z dnia 10 stycznia 2017 r., III SA/Gl 2104/15, CBOSA.

8 A. Gomułowicz, Ingerencyjny charakter prawa podatkowego [w:] J. Głuchowski (red.) Współczesne problemy prawa podatkowego. Teoria i praktyka. Księga jubileuszowa dedykowana Profesorowi Bogumiłowi Brzezińskiemu, tom. I, Warszawa 2019, s. 178 i n.; I. Nowak, Prawo podatkowe jako prawo publiczne w świetle jego odrębności jako gałęzi prawa - wybrane zagadnienia [w:] P. Ruczkowski (red.), Prawo - społeczeństwo - jednostka. Człowiek - najlepsza inwestycja, Kielce 2010, s. 83-92.

9 Zob. A. Nita, Wymuszona współpraca podatnika w procesie wymiaru podatku, „Państwo i Prawo” 2013, nr 12, s. 31 i n.; tenże, Niewładcze metody oddziaływania na treść powinności podatkowych [w:] I. Niżnik-Dobosz (red.), Zastosowanie idei public governance w prawie administracyjnym, Warszawa 2014, s. 185 i n.; I. Nowak, Wyłqczenie pracownika samorzq̨dowego organu podatkowego od udziału w postępowaniu podatkowym - zagadnienia ogólne, „Przegląd Podatków Lokalnych i Finansów Samorządowych” 2017, nr 8, s. 25-28; wyrok WSA w Gliwicach z dnia 27 stycznia 2017 r., III SA/Gl 1074/16, CBOSA.

10 Zasada ta ma odpowiednie zastosowanie również na gruncie procedur quasi-podatkowych (czynności sprawdzających, kontroli podatkowej, kontroli celnoskarbowej).

11 K. Dworniak, Ordynacja podatkowa. Komentarz, Legalis/el. 2003; S. Presnarowicz, Komentarz do art. 129 o.p..., LEX/el. 2020; I. Nowak, A. Nowak, Jawność postępowania podatkowego, „Rozprawy z Zakresu Nauk Prawnych” 2012, nr 3, s. 161-176.

12 M. Kośmider, Tajemnica skarbowa a informacje pochodzqce z banków i innych instytucji finansowych, „Kwartalnik Prawa Podatkowego” 2002, nr 2, s. 101-111; I. Nowak, I. Ledzion, Udostępnianie akt sprawy podatkowej, cz. I-II, „Przegląd Podatków Lokalnych i Finansów Samorządowy” 2017, nr 4-5, s. 17-21/17-23.

13 Wyrok WSA w Warszawie z dnia 15 maja 2018 r., II SA/Wa 123/18, CBOSA. 
państwowej (służbowej) ${ }^{14}$. Z tego też względu informacje objęte tajemnicą skarbową, znajdujące się w posiadaniu organów podatkowych, mogą być wykorzystywane tylko wewnątrz ich struktur organizacyjnych i wyłącznie na potrzeby podatkowe, natomiast wszelkie wyjątki muszą być expressis verbis określone przepisami prawa ${ }^{15}$.

Zgodnie z art. 294 § 1 o.p. do przestrzegania tajemnicy skarbowej obowiązani są: pracownicy izb administracji skarbowej; funkcjonariusze; pracownicy Krajowej Informacji Skarbowej; wójt, burmistrz (prezydent miasta), starosta, marszałek województwa oraz pracownicy urzędów ich obsługujących; członkowie samorządowych kolegiów odwoławczych, a także pracownicy biur tych kolegiów; minister właściwy do spraw finansów publicznych oraz pracownicy urzędu obsługującego tego ministra; Szef Krajowej Administracji Skarbowej; osoby odbywające staż, praktykę zawodową lub studencką w urzędzie obsługującym ministra właściwego do spraw finansów publicznych lub w innych organach podatkowych; przedstawiciele obcej władzy przebywający w siedzibach organów podatkowych, obecni w toku postępowania podatkowego lub obecni w toku czynności kontrolnych, w związku z wymianą informacji; członkowie Rady do Spraw Przeciwdziałania Unikaniu Opodatkowania; członkowie komisji doradczej i komisji do spraw pozasądowego rozstrzygania sporów oraz osoby, których dotyczy spór, ich przedstawiciele i pełnomocnicy, o których mowa w ustawie z dnia 16 października 2019 r. o rozstrzyganiu sporów dotyczących podwójnego opodatkowania oraz zawieraniu uprzednich porozumień cenowych ${ }^{16}$. Warto też zaznaczyć, że według $\S 4$ art. 294 o.p. do przestrzegania tajemnicy skarbowej obowiązane są również inne

14 D. Habrat, P. Majka, Upoważnienie inspektora kontroli skarbowej do ujawniania informacji stanowiq̨cych tajemnicę skarbowq, „Przegląd Podatkowy” 2013, nr 8, s. 36. 5 Wyrok NSA z dnia 13 czerwca 2013 r., I OSK 512/13, CBOSA.

16 Zachowanie tajemnicy skarbowej obowiązuje również po ustaniu zatrudnienia, zakończeniu stażu lub praktyki lub po ustaniu członkostwa w Radzie do Spraw Przeciwdziałania Unikaniu Opodatkowania (art. 294 § 3 o.p.). Ponadto osoby wskazane w art. 293 $\S 1$ o.p. są obowiązane do złożenia na piśmie przyrzeczenia następującej treści: „Przyrzekam, że będę przestrzegał tajemnicy skarbowej. Oświadczam, że są mi znane przepisy o odpowiedzialności karnej za ujawnienie tajemnicy skarbowej” - art. $294 \S 2$ o.p.; zob. także A. Melezini, Tajemnica skarbowa [w:] A. Melezini, D. Zalewski, Kontrola podatkowa przedsiębiorców, LEX/el. 2012. 
osoby, którym udostępniono informacje objęte tajemnicą skarbową, co oznacza, iż przepis ten należy rozumieć szeroko i trudno mówić o zamkniętym katalogu podmiotów obowiązanych do zachowania tajemnicy skarbowej ${ }^{17}$.

Z przepisu art. 294 o.p. wynika, że „tajemnica skarbowa jest instytucją, która powstała w celu zagwarantowania bezpieczeństwa danych wszystkich podmiotów uczestniczących w stosunkach prawnopodatkowych, ponieważ ochronie podlegają nie tylko dane przekazywane przez podatników, płatników lub inkasentów, ale także obejmuje ona ochroną dane samych organów podatkowych, na co wskazuje przepis art. $293 \S 2$ o.p."18. W konkluzji należy więc stwierdzić, że zakres tajemnicy skarbowej należy rozumieć możliwie szeroko, a obowiązek jej zachowania rozciąga się na wszystkie osoby mające styczność $z$ danymi ${ }^{19}$. Również w literaturze przedmiotu podkreśla się także, że instytucja tajemnicy skarbowej z jednej strony jest rodzajem „buforu, który zabezpiecza przed dostępem do informacji osoby, które mogłyby dopuścić się przestępstwa korupcyjnego, polegającego np. na sprzedawaniu informacji skarbowych w zamian za otrzymanie pewnej kwoty pieniężnej” ${ }^{20}$, natomiast z drugiej jest „wentylem bezpieczeństwa” dla informacji gromadzonych przez organy podatkowe, których ujawnienie grozi sankcjami karnymi ${ }^{21}$.

W uzupełnieniu wcześniejszych uwag dotyczących zakresu obowiązywania tajemnicy skarbowej należy zaznaczyć, że obowiązek ochrony informacji stanowiących tajemnicę skarbową ma charakter

17 J. Jezierski, Tajemnica skarbowa w Ordynacji podatkowej [w:] Księga pamiq̨tkowa ku czci docenta Eligiusza Drgasa, Toruń 1998, s. 56; D. Benduch, Tajemnica skarbowa, „Monitor Podatkowy” 2014, nr 15, Legalis/el.

18 J. Kondratowska-Muszyńska, Komentarz do art. 294 o.p. [w:] H. Dzwonkowski (red.), Ordynacja podatkowa. Komentarz, Legalis/el. 2020.

19 R. Mastalski, Komentarz do art. 293 o.p. [w:] B. Adamiak, J. Borkowski, P. Borszowski, R. Mastalski, J. Zubrzycki, Ordynacja podatkowa. Komentarz, Wrocław 2017, s. 1645; C. Kosikowski, Komentarz do art. 293 o.p. [w:] J. Brolik, R. Dowgier, L. Etel, C. Kosikowski, P. Pietrasz, M. Popławski, S. Presnarowicz, W. Stachurski, Ordynacja podatkowa. Komentarz, LEX/el. 2013; postanowienie NSA z dnia 3 września 2013 r., II FSK 1271/13, CBOSA.

20 A. Melezini, Prawne instrumenty zapobiegania i zwalczania korupcji przez kontrolę skarbowq, LEX/el. 2012.

21 Tamże. 
kategoryczny i obwarowany jest sankcją karną za bezprawne ich ujawnienie $^{22}$. Zgodnie bowiem $\mathrm{z}$ art. $306 \S 1-2$ o.p. kto, będąc obowiązanym do zachowania tajemnicy skarbowej, ujawnia informacje objęte tą tajemnicą, podlega karze pozbawienia wolności do lat 5, przy czym, jeśli to dotyczy informacji pochodzących od banków (art. 182 o.p.) - kara pozbawienia wolności wynosi od 6 miesięcy do lat $5^{23}$. Nie sposób przy tym nie zauważyć słusznego postulatu zgłoszonego przez B. Brzezińskiego, aby ustawodawca dokonał przekwalifikowania „przypadków naruszenie tajemnicy skarbowej z przestępstwa wnioskowego na przestępstwo ścigane $\mathrm{z}$ urzędu. Państwo żąda od podatników i gromadzi coraz więcej informacji o nich - ale ściganie tych pracowników administracji podatkowej, którzy informacje takie przekazują bądź rozpowszechniają $\mathrm{w}$ sposób niezgodny $\mathrm{z}$ prawem pozostawia samym podatnikom”24.

\section{Ujawnienie tajemnicy skarbowej - rys historyczny art. 299b Ordynacji podatkowej}

Art. 299b o.p. został dodany do ustawy Ordynacja podatkowa aktem prawnym z dnia 16 listopada 2006 r. o zmianie ustawy - Ordynacja podatkowa oraz o zmianie niektórych innych ustaw ${ }^{25}$ i zaczął obowiązywać

22 Szerzej J. Gliniecka, Odpowiedzialność prawna zwiq̨zana z naruszeniem obowiq̨zku zachowania tajemnicy finansowej, „Gdańskie Studia Prawnicze” 2009, t. 21, s. 167186; D. Zalewski, Naruszenie tajemnicy skarbowej a legalność postępowania podatkowego, „Monitor Podatkowy” 2019, nr 11, Legalis/el.

23 Jeżeli sprawca czynu określonego w art. 306 § 1 lub 2 o.p. działa nieumyślnie, podlega karze pozbawienia wolności do lat 2; zob. także E. Janik, Tajemnica skarbowa - głos w dyskusji [w:] P. Malinowski, T. Nowak, A. Sędkowska (red.), Kontrola podatkowa, skarbowa i celna, LEX/el. 2013; wyrok WSA w Gliwicach z dnia 26 lutego 2019 r., I SA/Gl 1037/18, CBOSA.

24 B. Brzeziński, O idei równoważenia praw i obowiq̨zków podatników oraz administracji podatkowej w projekcie nowej Ordynacji podatkowej [w:] J.M. Salachna, K. Stelmaszczyk, P. Borszowski, Prawo i administracja dla regionu nr 4. Zagadnienia prawnofinansowe, Wałbrzych 2016, s. 139.

25 Na podstawie art. 1 pkt 37 ustawy z dnia 16 listopada 2006 r. (Dz.U. z 2006 r. Nr 217, poz. 1590), dalej: u.z.u.o.p. 
od dnia 1 stycznia 2007 r. $^{26}$ Zgodnie z uzasadnieniem rządowego projektu powyższego aktu prawnego art. 299b o.p. miał umożliwić w szczególności obronę wizerunku służb skarbowych przed niezasadnymi zarzutami medialnymi, w których podatnik sam ujawnia informacje chronione tajemnicą skarbową. Również zdaniem Ministra Finansów „poprzez brak możliwości uchylenia tajemnicy skarbowej w konkretnej sprawie organy kontroli skarbowej i organy podatkowe pozbawione były również możliwości reakcji i odpowiedzi na publikacje prasowe oraz telewizyjne dotyczące ich działalności w tych sprawach. Ujawnianie w mediach tylko wybranych informacji, często wyrwanych z kontekstu całej sprawy, przedstawiających tylko część stanu faktycznego przy jednoczesnej niemożności przedstawienia przez organy kontroli skarbowej i organy podatkowe własnych argumentów, powodowało dezinformację i stawiało organy państwa w sytuacji braku możliwości obrony. Mogło to prowadzić do naruszenia przysługującego obywatelom prawa do informacji o działaniach administracji rządowej oraz do kształtowania negatywnego wizerunku i podważania wiarygodności organów kontroli skarbowej i organów podatkowych w ocenie społeczeństwa. W szczególności wskazane przepisy umożliwiają obronę wizerunku służb skarbowych przed nieuzasadnionymi zarzutami medialnymi, w których podatnik sam ujawnia informacje chronione tajemnicą skarbową, ale tylko w części, która służy realizacji jego interesu, bez zaprezentowania dalszej części niejednokrotnie dla niego niekorzystnej. Podkreślić należy, że rzetelne informowanie przez służby skarbowe opinii publicznej o działaniach podatników w sytuacji, gdy spełnione są przesłanki stosowania wskazanych przepisów, nie może być odbierane jako naruszanie ich dobrego imienia. W grę wchodzi bowiem wyważenie różnych dóbr i wartości”27.

\footnotetext{
Zob. art. 7 u.z.u.o.p.

7 Pismo Ministra Finansów z dnia 23 stycznia 2007 r., http://orka2.sejm.gov.pl/IZ5.nsf/main/5F739689.
} 


\section{Zgoda Szefa Krajowej Administracji Skarbowej jako warunek sine qua non ujawnienia tajemnicy skarbowej}

Zgodnie z art. 299b § 1 o.p. Szef Krajowej Administracji Skarbowej ${ }^{28}$ może wyrazić zgodę na ujawnienie przez naczelników urzędów skarbowych, naczelników urzędów celno-skarbowych, dyrektorów izb administracji skarbowej, określonych informacji stanowiących tajemnicę skarbową, z wyłączeniem informacji stanowiących tajemnicę inną niż skarbowa i objętych ochroną na podstawie odrębnych ustaw, wskazując jednocześnie sposób udostępnienia i wykorzystania ujawnianych informacji. Analiza językowa cytowanego przepisu przekonuje zatem, że zgodę na ujawnienie tajemnicy skarbowej udziela jedynie Szef Krajowej Administracji Skarbowej i wyłącznie na wniosek państwowych organów administracji podatkowej enumeratywnie wskazanych w art. 299b § 1 o.p. ${ }^{29}$ Rozumując a contrario, inne czynne podmioty stosunku podatkowoprawnego nie uzyskały „umocowania” do występowania do Szefa Krajowej Administracji Skarbowej o ujawnienie na podstawie art. 299b o.p. określonych informacji objętych tajemnicą skarbową, w tym m.in. Minister Finansów, nie wspominając już np. o Prezesie Narodowego Funduszu

28 Pierwotnie uprawnienie do ujawnienia tajemnicy skarbowej przysługiwało Ministrowi Finansów. Natomiast z dniem 1 marca 2017 r. w wyniku tzw. konsolidacji administracji podatkowej służby celnej i kontroli skarbowej w Krajową Administrację Skarbową, powyższa kompetencja należy do jej Szefa - art. 38 pkt 74 w związku z art. 260 ab initio ustawy z dnia 16 listopada 2016 r. Przepisy wprowadzające ustawę o Krajowej Administracji Skarbowej (Dz.U. z 2016 r., poz. 1948); zob. także I. Nowak, National Revenue Administration - current organisational and financial problems, „Prawo Budżetowe Państwa i Samorządu” 2020, nr 2, s. 37-65; tenże Krajowa Administracja Skarbowa w liczbach, „Kazus Podatkowy” 2020, nr 4, s. 24-25; Funkcjonariusze celni w strukturze Krajowej Administracji Skarbowej - uwagi wybrane, „Kwartalnik Prawa Podatkowego" 2019, nr 1, s. 37-65.

29 W piśmiennictwie zgodę Szefa Krajowej Administracji Skarbowej określa się jako tzw. wewnętrzny akt administracyjny - B. Brzeziński, M. Kalinowski M. Masternak, A. Olesińska, J. Orłowski, Ordynacja podatkowa. Komentarz, tom II, Toruń 2007, s. 770, P. Pietrasz, Komentarz do art. 43 u.k.s. [w:] P. Pietrasz, W. Stachurski, Ustawa o kontroli skarbowej. Komentarz, Wrocław 2011, s. 413. 
Zdrowia, który nie ma żadnych instrumentów prawnych do pozyskiwania tychże informacji ${ }^{30}$.

Zgoda Szefa Krajowej Administracji Skarbowej może być wydana wyłącznie na wniosek - nigdy zaś z urzędu ${ }^{31}$ - i nie może przybierać charakteru generalnego, ale musi wskazywać indywidualnie oznaczony czynny podmiot stosunku podatkowoprawnego, spośród wymienionych w art. 299b § 1 o.p., który o nią wnioskował. Co więcej, zakres zgody Szefa Krajowej Administracji Skarbowej o ujawnieniu na podstawie art. 299b o.p. określonych informacji objętych tajemnicą skarbową musi być sformułowany precyzyjnie, tak aby „ramy prawne” ograniczenia praw dłużnika podatkowego były w pełni czytelne i zrozumiałe dla wnioskujących organów ${ }^{32}$. Ponadto zgoda wydana przez Szefa Krajowej Administracji Skarbowej nie może być stosowana przez ujawniający czynny podmiot stosunku podatkowoprawnego w sposób rozszerzający, gdyż ujawnianie tych informacji stanowi odstępstwo od zasady ich tajności ${ }^{33}$.

Naczelnik urzędu skarbowego, naczelnik urzędu celno-skarbowego lub dyrektor izby administracji skarbowej ${ }^{34}$ powinni zawsze dokonywać wstępnych ocen, czy w składanych wnioskach do Szefa Krajowej Administracji Skarbowej o wyrażenie zgody na ujawnienie określonych danych stanowiących tajemnicę skarbową w tychże sprawach zachodzą przesłanki z art. 299b o.p. ${ }^{35}$ Ponadto państwowe organy podatkowe muszą precyzyjnie uzasadniać, z jakiego powodu zachodzi potrzeba „ujawniania informacji objętych tajemnicą skarbową i w odniesieniu do jakich podmiotów oraz w jakim zakresie i w jakiej formie"36. Pamiętać zatem należy, że „użyty w art. 299b § 3 o.p. zwrot «na uzasadniony wniosek» danego organu oznacza, że żądanie wyrażenia zgody przez Szefa Krajowej Admini-

\footnotetext{
Wyrok NSA z dnia 20 lutego 2020 r., II GSK 3719/17, CBOSA.

Analogicznie W. Stachurski, Komentarz do art. 299b o.p..., LEX/el. 2020; C. Kosikowski, Komentarz do art. 299b o.p..., LEX/el. 2013.

32 Por. wyrok WSA w Warszawie z dnia 26 stycznia 2007 r., I SA/Wa 1774/06, CBOSA.

33 Por. G. Pelewicz, Komentarz do art. 34 u.k.s. [w:] K. Kandut, A. Sędkowska (red.), Ustawa o kontroli skarbowej. Komentarz, LEX/el. 2014.

34 Art. 299b § 3 o.p.

35 Wyrok WSA w Szczecinie z dnia 14 czerwca 2017 r., I SA/Sz 352/17, CBOSA; wyrok WSA w Warszawie z dnia 7 lipca 2011 r., III SA/Wa 2335/10, CBOSA.

36 C. Kosikowski, Komentarz do art. 299 b o.p..., LEX/el. 2013.
} 
stracji Skarbowej winno być umotywowane pod względem merytorycznym, wskazując istotne podstawy odstąpienia od szczegółowo normowanych w przepisach działu 7 o.p. zasad ochrony oraz udostępniania informacji objętych tajemnicą skarbową"37. Zatem naczelnik urzędu skarbowego, naczelnik urzędu celno-skarbowego lub dyrektor izby administracji skarbowej, zanim zawnioskuje do Szefa Krajowej Administracji Skarbowej, musi przede wszystkim dokonać prawidłowej wykładni art. 299b o.p. m.in. udzielając sobie odpowiedzi na 2 pytania: czy wniosek ma dotyczyć zgody na ujawnienie tajemnicy skarbowej i czy jest właściwie umotywowany $^{38}$. Oznacza to, że uzasadnienie wniosku musi w sposób przekonujący ukazywać konkretne okoliczności ${ }^{39}$, albowiem „w praktyce możliwość ujawnienia informacji stanowiących tajemnicę skarbową chroni organy podatkowe przed sytuacją, w której strona postępowania upublicznia nieprawdziwe informacje o toczącym się postępowaniu, a tajemnica skarbowa wyklucza sprostowanie tych informacji” ${ }^{* 0}$.

Szef Krajowej Administracji Skarbowej może wyrazić zgodę na ujawnienie przez naczelników urzędów skarbowych, naczelników urzędów celno-skarbowych, dyrektorów izb administracji skarbowej określonych informacji stanowiących tajemnicę skarbową na każdym etapie prowadzonego postępowania podatkowego lub postepowań quasi-podatkowych (kontroli podatkowej, kontroli celno-skarbowej), a zatem nawet wtedy, gdy nie zostały ono jeszcze zakończone ${ }^{41}$. Co więcej, zgodnie $\mathrm{z}$ regułą interpretacyjną a maiori ad minus w świetle przepisu art. 299b o.p. jest możliwe, aby Szef Krajowej Administracji Skarbowej, któ-

37 B. Brzeziński, M. Kalinowski, A. Olesińska (red.), Ordynacja podatkowa. Komentarz praktyczny, Gdańsk 2017, s. 1379.

38 Wyrok NSA z dnia 7 maja 2018 r., II FSK 2835/17, CBOSA.

39 Muszą być to informacje posiadające przymiot określoności (in concreto) - wyrok NSA z dnia 7 maja 2018 r., II FSK 2835/17, CBOSA.

40 K. Sołoniewicz, Tajemnica skarbowa [w:] A. Mariański (red.), Ordynacja podatkowa 2017. Poradnik dla praktyków, Legalis/el. 2017.

41 Por. interpelacja poselska nr 5918 do Ministra Finansów z dnia 20 grudnia 2006 r. w sprawie ujawniania tajemnicy skarbowej podatników na podstawie art. 34 ust. 1a-1c ustawy o kontroli skarbowej oraz art. 299b ustawy Ordynacja podatkowa, http://orka2.sejm.gov.pl/IZ5.nsf/main/24CFA7AC. 
ry wydał zgodę na ujawnienie określonych informacji stanowiących tajemnicę skarbową, mógł ją cofnąć lub zmienić jej treść ${ }^{42}$.

Szef Krajowej Administracji Skarbowej w udzielonej zgodzie musi explicite sformułować informacje, które mogą być ujawnione, w tym również sposób ich udostępnienia i wykorzystania ${ }^{43}$. Innymi słowy, dopiero po uzyskaniu zgody Szefa Krajowej Administracji Skarbowej dopuszczalne staje się ujawnienie przez państwowe organy podatkowe określonych informacji stanowiących tajemnicę skarbową ${ }^{44}$. Ponadto z konstrukcji przepisu art. 299b o.p. należy wyinterpretować, że „ujawnieniu mogą podlegać dane stanowiące cały materiał dowodowy w sprawie bądź tylko jego część, wybrane dokumenty, dane, informacje itd."45.

Kwestią dyskusyjną jest termin, w jakim Szef Krajowej Administracji Skarbowej powinien wyrazić lub też nie zgodę na ujawnienie określonych informacji stanowiących tajemnicę skarbową, ponieważ przepis art. 299b o.p. tego zagadnienia nie normuje. Wydaje się jednak, że wydanie zgody, ewentualnie jej odmowa, powinny nastąpić bez zbędnej zwłoki ${ }^{46}$.

\section{Przesłanki uzasadniające wyrażenie zgody na ujawnienie tajemnicy skarbowej w świetle art. 299b o.p.}

\subsection{Uwagi ogólne}

Regulacja prawna z art. 299b o.p. opiera się na zasadzie ograniczonego uznania administracyjnego ${ }^{47}$, jednakże dyskrecjonalny charakter zgody nie przekreśla reguły, według której jej zakres udzielenia jest związany dyrektywami ustawowymi z art. 299b § 1-3 o.p., nakazującymi dokonanie

42 C. Kosikowski, Komentarz do art. 299 b o.p..., LEX/el. 2013.

43 W. Stachurski, Komentarz do art. 299 b o.p..., LEX/el. 2020; B. Brzeziński, M. Kalinowski, A. Olesińska (red.), Ordynacja..., s. 1379.

44 Tamże.

45 G. Pelewicz, Komentarz do art. 34 u.k.s..., LEX/el. 2014.

46 Podobnie B. Brzeziński, M. Kalinowski M. Masternak A. Olesińska, J. Orłowski, Ordynacja..., s. 771.

47 Tamże, s. 770. 
oceny wniosku naczelnika urzędu skarbowego, naczelnika urzędu celno-skarbowego lub dyrektora izby administracji skarbowej tylko po wszechstronnym i wnikliwym rozważeniu oraz dokładnym wyjaśnieniu wszystkich okoliczności faktycznych i prawnych. Zasadniczy jednak sprzeciw budzi przy tym przede wszystkim fakt, że wydawanie zgody nie następuje w ramach sformalizowanej procedury podatkowej ${ }^{48}$, przez co nie przebiera ona formy indywidualnego aktu podatkowego (postanowienia/decyzji $)^{49}$, wydawanego w jurysdykcyjnym postępowaniu podatkowym, czy postępowaniach quasi-podatkowych ${ }^{50}$, a jedynie ogranicza się do zastrzeżenia, że wyrażenie zgody powinno nastąpić w formie pisemnej. W konsekwencji brak określonej w przepisie art. 299b o.p. formy czynności prawnej Szefa Krajowej Administracji Skarbowej sprawia m.in., że zainteresowane podmioty, odnośnie których nastąpiło ujawnienie określonych informacji stanowiących tajemnicę skarbowe, nie są nawet o tym fakcie informowane ${ }^{51}$. W pełni zatem należy podzielić stanowisko R. Mastalskiego, że konstrukcja prawna art. 299b o.p., biorąc pod uwagę liczny krąg podmiotów, które mogą występować z wnioskiem o ujawnienie tajemnicy skarbowej, nie chroni należycie interesów biernych podmiotów stosunków podatkowoprawnych ${ }^{52}$.

Wykładnia zarówno językowa, jak i celowościowa art. 299b § 1-2 o.p. prowadzi do wniosku, że wyrażenie przez Szefa Krajowej Admini-

48 Zob. I. Nowak, Zwiqzanie organu podatkowego wydanq i doręczonq decyzjq, „Przegląd Podatków Lokalnych i Finansów Samorządowych” 2018, nr 10, s. 23-28.

49 W. Stachurski, Komentarz do art. 299b o.p..., LEX/el. 2020.

50 Wyrok WSA w Szczecinie z dnia 14 czerwca 2017 r., I SA/Sz 352/17, CBOSA.

51 Biorąc pod uwagę dyskrecjonalność Szefa Krajowej Administracji Skarbowej, in plus należy ocenić postulat, który pojawił się w art. $119 \S 5$ projektu ustawy Ordynacja podatkowa z dnia 6 października 2017 r., przygotowanego przez Komisję Kodyfikacyjną Ogólnego Prawa Podatkowego, w którym wprowadzono obowiązek organu ujawniającego informacje stanowiące tajemnicę skarbową poinformowania zainteresowanych o tym ujawnieniu jako następstwo realizacji zasady ogólnej związanej z prowadzeniem postępowania w sposób budzący zaufanie do organów podatkowych - zob. L. Etel (red.), Nowa Ordynacja podatkowa. Z prac Komisji Kodyfikacyjnej Ogólnego Prawa Podatkowego, Białystok 2017, s. 210.

52 R. Mastalski, Komentarz do art. 299 b o.p..., s. 1660; C. Kosikowski, Komentarz do art. 294 o.p. [w:] H. Dzwonkowski, A. Huchla, C. Kosikowski, Ordynacja podatkowa. Komentarz, LEX/el. 2003; M. Szubiakowski, Problemy prawnej regulacji tajemnicy skarbowej, „Zeszyty Naukowe Sądownictwa Administracyjnego” 2014, nr 4, s. 14. 
stracji Skarbowej zgody na ujawnienie określonych informacji objętych tajemnicą skarbową jest możliwe, gdy wystąpi podstawowa przesłanka w postaci ważnego interesu publicznego, a ponadto jest spełnione jedno z dwóch dodatkowych kryteriów, tzn. jest to konieczne dla osiągnięcia celów kontroli podatkowej, kontroli celno-skarbowej lub postępowania podatkowego lub jeżeli ujawnienie tych informacji urzeczywistni prawo obywateli do ich rzetelnego informowania o działaniach organów podatkowych i jawności życia publicznego ${ }^{53}$. Ponadto wyrażenie przez Szefa Krajowej Administracji Skarbowej powyższej zgody jest możliwe, jeżeli jednocześnie nie zachodzi tzw. przesłanka negatywna z $\S 1$ art. 299b o.p., czyli nie dojdzie do objęcia „określonej informacji tajemnicą inną niż skarbowa, która chroniona jest na podstawie odrębnych ustaw”54. Inaczej rzecz ujmując, w trybie art. 299b o.p. mogą być ujawniane wyłącznie informacje stanowiące tajemnicę skarbową ${ }^{55}$, z wyłączeniem informacji objętych ochroną na podstawie odrębnych aktów prawnych ${ }^{56}$, dotyczących przykładowo tajemnicy prokuratorskiej, adwokackiej, radcowskiej czy też dziennikarskiej ${ }^{57}$.

Wszystkie przesłanki pozytywne z $\S 2$ art. 299b o.p., a dotyczące udzielenia zgody na ujawnienie tajemnicy skarbowej, zostały sformułowane przy użyciu tzw. pojęć niedookreślonych (klauzul generalnych) ${ }^{58}$, co rodzi istotne niebezpieczeństwo niewłaściwego wartościowania przez Szefa Krajowej Administracji Skarbowej wniosków, powodując jednocześnie dużą swobodę w wyrażeniu zgody ${ }^{59}$. Nic więc dziwnego, że w piśmien-

53 W. Stachurski, Komentarz do art. 299b o.p..., LEX/el. 2020; wyrok NSA z dnia 10 stycznia 2020 r., II FSK 1522/19, CBOSA; wyrok WSA w Gliwicach z dnia 26 lutego 2019 r., I SA/Gl 1037/18, CBOSA.

54 W. Stachurski, Komentarz do art. 299 b o.p..., LEX/el. 2020.

55 „W praktyce organów podatkowych dotyczy to głównie informacji objętych tajemnicą bankową oraz tajemnicą związaną z obrotem instrumentami finansowymi” - W. Stachurski, Komentarz do art. 299 b o.p..., LEX/el. 2020.

56 R. Mastalski, Komentarz do art. 2996 o.p..., s. 1660.

57 Por. D. Zalewski, A. Melezini, Ustawa o kontroli skarbowej. Komentarz (do art. 34), Legalis/el. 2012; J. Kulicki, Kontrola skarbowa. Komentarz (do art. 34), LEX/el. 2013.

58 Szerzej na ten temat P. Borszowski, Określenia nieostre i klauzule generalne w prawie podatkowy, Warszawa 2017.

59 Wyrok NSA z dnia 7 maja 2018 r., II FSK 2835/17, CBOSA; P. Szustakiewicz, Dostęp do informacji publicznej, Legalis/el. 2019. 
nictwie stawia się zasadne pytanie, czy dla „obrony wizerunku służb skarbowych przed nieuzasadnionymi zarzutami medialnymi potrzebne jest uchwalanie specjalnych przepisów (...)? A jeżeli już, to można wątpić, czy użyta w przepisie formuła w uzasadnionych przypadkach spełnia konstytucyjny wymóg prawa dookreślonego. Należałoby w najgorszym wypadku dodać, czym te przypadki mogą być uzasadnione (wystarczy wyliczenie modo limitativo)",60.

Przedstawione uwagi prowadzą do ogólnego spostrzeżenia, że ustawodawca nie zdefiniował, co należy rozumieć w myśl art. 299b o.p. pod pojęciami: „ważnego interesu podatnika”, „konieczności osiągnięcia celów kontroli podatkowej, kontroli celno-skarbowej lub postępowania podatkowego”; „urzeczywistnienia prawa obywateli do ich rzetelnego informowania o działaniach organów podatkowych i jawności życia publicznego”. W tej sytuacji należy sięgnąć do znaczenia tych zwrotów wypracowanego przez doktrynę i orzecznictwo, pamiętając jednakże, że „nawet najlepiej opisany i wielopłaszczyznowo wyjaśniony przez teoretyków i dogmatyków prawa zwrot ocenny, jeżeli zostanie nieprawidłowo wprowadzony do treści przepisów, nie będzie mógł być jednoznacznie zinterpretowany"61. Niestety, w przepisie art. 299b o.p. mamy do czynienie z takim „mankamentem”62.

\subsection{Ważny interes publiczny}

Klauzula generalna ważnego interesu publicznego, choć jest kategorią ocenną, nie może być interpretowana rozszerzająco ani prowadzić do ograniczenia innych odrębnych praw podatników ${ }^{63}$. Także zdaniem judy-

60 B. Brzeziński, Opinia o rzq̨dowym projekcie ustawy o zmianie ustawy Ordynacja podatkowa oraz o zmianie niektórych innych ustaw (Druk sejmowy 731), http://orka.sejm.gov.pl/WydBAS.nsf/0/87DA9D44CCEE40D3C125724500349923/\$fi le/O2006.pdf.

61 Tak M. Münnich, Nieostre zwroty ocenne w polskim prawie podatkowym, Lublin 2017, s. 220.

62 Analogicznie P. Krawczyk, Czy tajemnica skarbowa jest potrzebna? [w:] R. Dowgier (red.) Ordynacja podatkowa. Wokół nowelizacji, Białystok 2009, s. 77.

63 Wyrok TK z dnia 8 lipca 2008 r., K 46/07, LEX/el. 
katury pojęcie ważnego interesu publicznego, pomimo że jest pojęciem szerokim i nieostrym, to nie ulega jednak wątpliwości, iż obejmuje ono interes ogółu (określonej wspólnoty), a nie jedynie interesy indywidualne. Przy czym konkretyzację tej wspólnoty (społeczności), której interes powinien być uwzględniony, wyznacza zakres żądanej informacji ${ }^{64}$. Zatem ważny interes publiczny musi mieć kwalifikowany charakter (nie może to być jakikolwiek interes) ${ }^{65}$ i to wyłącznie nadzwyczajne względy powinny decydować o przyjęciu, że zachodzi ${ }^{66}$. Przykładowo ważny interes publiczny to dyrektywa postępowania nakazująca taki sposób postępowania, który ma na uwadze respektowanie wartości wspólnych dla całego społeczeństwa, takich jak sprawiedliwość, bezpieczeństwo, zaufanie obywateli do organów władzy, sprawność działania aparatu administracji publicznej itp. ${ }^{67}$

Reasumując, kryterium ważnego interesu publicznego jako kategoria ocenna musi być w każdym wypadku indywidualnie ustalane w sposób „wielopłaszczyznowy”68 przez organy administracji podatkowej w ramach trybu „procedowania” na gruncie art. 299b o.p. ${ }^{69}$

64 Wyrok WSA w Gliwicach z dnia 26 lutego 2019 r., I SA/Gl 1037/18, CBOSA; wyrok NSA z dnia 12 czerwca 2014 r., I OSK 2787/13, CBOSA.

65 Por. wyrok NSA z dnia 12 czerwca 2014 r., I OSK 2787/13, CBOSA.

66 Wyrok TK z dnia 27 lutego 2002 r., K 47/01, LEX/el.; wyrok NSA z dnia 7 maja 2018 r., II FSK 2835/17, CBOSA.

67 Wyrok WSA w Poznaniu z dnia 9 maja 2018 r., III SA/Po 146/18, CBOSA; wyrok WSA we Wrocławiu z dnia 23 listopada 2016 r., III SA/Wr 120/16, CBOSA; wyrok WSA w Warszawie z dnia 6 listopada 2014 r., V SA/Wa 997/14, CBOSA; wyrok WSA w Łodzi z dnia 24 listopada 2010 r., I SA/Łd 1099/10, CBOSA.

68 A. Choduń, A. Gomułowicz, A.P. Skoczylas, Klauzule generalne i zwroty niedookreślone $w$ prawie podatkowym i administracyjnym. Wybrane zagadnienia teoretyczne i orzecznicze, LEX/el 2013.

69 Por. wyrok WSA w Łodzi z dnia 27 czerwca 2019 r., I SA/Łd 165/19, CBOSA; wyrok NSA z dnia 17 czerwca 2009 r., II FSK 219/08, CBOSA; wyrok NSA z dnia 26 września 2002 r., III SA 659/01, CBOSA. 


\subsection{Urzeczywistnienie prawa obywateli do ich rzetelnego informowania o działaniach organów podatkowych i jawności życia publicznego}

Odnosząc się do kryterium urzeczywistnienia prawa obywateli do ich rzetelnego informowania o działaniach organów podatkowych i jawności życia publicznego, należy uznać je bez wątpienia za pojęcia niedookreślone, które powinny być „wykładane” w powiązaniu z art. 61 Konstytucji $\mathrm{RP}^{70}$, który w ust. 1 ustanawia prawo do uzyskania informacji o działalności organów władzy publicznej. Prawo to może zostać ograniczone tylko ze względu na określoną w ustawie ochronę wolności i praw innych osób i podmiotów gospodarczych oraz ochronę porządku publicznego, bezpieczeństwa lub ważnego interesu gospodarczego państwa (por. art. 61 ust. 3 Konstytucji RP) ${ }^{71}$. Innymi słowy, pomimo że konstytucyjne prawo do informacji publicznej powinno służyć jak najszerszemu obywatelskiemu dostępowi do danych publicznych, zaś zasady jawności życia publicznego i transparentności działań władzy publicznej mają sprzyjać sprawowaniu społecznej kontroli przez wszystkich obywateli, to jednak nie ma ono charakteru absolutnego ${ }^{72}$. Tym samym ujawnienie określonych informacji stanowiących tajemnicę skarbową nie może następować np. w trybie informowania obywateli o działaniach organów podatkowych w ramach działu VIII k.p.a. - „Skargi i wnioski” lub ustawy z dnia 6 września 2001 r. o dostępie do informacji publicznej ${ }^{73}$.

70 Ustawa z dnia 2 kwietnia 1997 r. Konstytucja Rzeczypospolitej Polskiej (Dz.U. z 1997 r., Nr 78, poz. 483 ze zm.), dalej: Konstytucja RP.

71 Wyrok WSA w Gliwicach z dnia 26 lutego 2019 r, I SA/Gl 1037/18, CBOSA.

72 Por. wyrok WSA w Poznaniu z dnia 22 lipca 2020 r., IV SA/Po 264/20, CBOSA; wyrok NSA z dnia 30 kwietnia 2020 r., I OSK 4105/18, CBOSA.

73 Tekst jedn. Dz.U. z 2020 r., poz. 2176 ze zm.; zob. R. Marek, Tajemnica skarbowa a dostęp do informacji publicznej, Legalis/el. 


\subsection{Konieczność osiągnięcia celów kontroli podatkowej, kontroli celno-skarbowej lub postępowania podatkowego}

Co do zasady celem postępowania podatkowego jest rozstrzyganie w drodze zewnętrznych aktów władczych (ustalających lub określających) sytuacji prawnej konkretnie oznaczonego podatnika w jego indywidualnie sprawie $^{74}$, wynikających ze szczegółowego (materialnego) prawa podatkowego $^{75}$. Celem zaś kontroli podatkowej jest sprawdzenie, czy kontrolowani wywiązują się z obowiązków wynikających z przepisów prawa podatkowego $^{76}$. Natomiast rolą kontroli celno-skarbowej (tzw. kontroli twardej) w przeciwieństwie do kontroli podatkowej (tzw. kontroli miękkiej) „ma być przede wszystkim szybka reakcja kontrolna na popełniane przestępstwa i wykroczenia skarbowe w sposób umożliwiający skuteczne wyegzekwowanie przez państwo dochodów z podatków i ceł, opłat oraz niepodatkowych należności budżetowych celem ochrony interesów Skarbu Państwa oraz ochrony obszaru celnego Unii Europejskiej”77.

Biorąc powyższe pod uwagę, powstaje zasadne pytanie: $\mathrm{w}$ jaki sposób ujawnienie informacji stanowiących tajemnicę skarbową miałoby okazać się konieczne dla osiągnięcia celów kontroli podatkowej, kontroli celno-skarbowej lub postępowania podatkowego ${ }^{78}$. W rezultacie należy

74 I. Nowak, Zasada jawności w jurysdykcyjnym postępowaniu podatkowym na tle inkwizycyjnego stosunku podatkowoprawnego, „Przegląd Podatków Lokalnych i Finansów Samorządowych” 2020, nr 7, s. 25-31; wyrok WSA w Warszawie z dnia 25 sierpnia 2011 r., II SA/Wa 1323/11, CBOSA; postanowienie WSA w Warszawie z dnia 5 października 2009 r., II SA/Wa 1068/09, CBOSA; wyrok NSA z dnia 28 października 1992 r., SA/Wr 841/92, CBOSA.

75 A. Gomułowicz, J. Małecki, Podatki i prawo podatkowe, Warszawa 2010, s. 435; A. Hanusz, A. Niezgoda, P. Czerski, Dochody jednostek samorzqdu terytorialnego, Warszawa 2009, s. 15 i n.; W. Chróścielewski, W. Nykiel, Postępowanie podatkowe w świetle Ordynacji podatkowej, Warszawa 2000, s. 11-14; wyrok NSA z dnia 22 marca 2006 r., II FSK 563/05, CBOSA.

76 Bez wątpienia cel kontroli podatkowej jest szerszy od czynności sprawdzających wyrok NSA z dnia 20 września 2017 r., I FSK 1993/15, CBOSA; wyrok NSA z dnia 3 marca 2016 r., I FSK 1957/15, CBOSA.

77 A. Melezini, Komentarz do art. 54 u.K.A.S. [w:] K. Teszner (red.) Krajowa Administracja Skarbowa. Komentarz, LEX/el. 2018.

78 P. Krawczyk, Czy tajemnica..., s. 77. 
dojść do wniosku, że powyższa przesłanka uchybia zasadzie proporcjonalności pomiędzy ochroną interesów prywatnych a ochroną interesów publicznych, eksponując expressis verbis interes fiskalny organów podatkowych $^{79}$, pamiętając jednocześnie, że dłużnik podatkowy nie dysponuje żadnymi w tej kwestii ,instrumentami prawnymi” zapewniającymi mu należytą ochronę ${ }^{80}$. De facto upubliczniona informacja jest wyrażeniem przez organy podatkowe jednostronnej opinii, wskutek której kontrahenci podatnika, dowiadując się, że jest on przedmiotem zainteresowania organów podatkowych, z obawy przed potencjalnymi problemami, mogą rezygnować ze współpracy ${ }^{81}$. Natomiast „między bajki można włożyć prawo podatników do dochodzenia odszkodowań w sytuacji, gdy ujawnienie tej tajemnicy narazi ich na szkodę"82.

\section{Podsumowanie}

Tajemnica skarbowa jako jedna z wielu tajemnic ustawowo chronionych w polskim porządku prawnym stanowi bez wątpienia pożądany „instrument prawny" biernych podmiotów stosunków podatkowoprawnych ${ }^{83}$, a w szczególności w postępowaniu podatkowym i procedurach quasi-podatkowych ${ }^{84}$ odzwierciedlający ochronę ich konstytucyjnego prawa do

79 Szerzej na ten temat J. Serwacki, Tajemnica skarbowa [w:] M. Grzybowski (red.), Państwo demokratyczne, prawne i socjalne. Księga jubileuszowa dedykowana Profesorowi Zbigniewowi Antoniemu Maciagowi, Kraków 2014, s. 364; W. Nykiel, O potrzebie równowagi między uprawnieniami i obowiq̨zkami podatnika oraz organów podatkowych, „Prawo i Podatki” 2005, nr 12, s. 25-28.

80 Szerzej J. Gliniecka, Wyjatek od zasady tajemnicy skarbowej czy zaprzeczenie jej istoty?, „Prawo i Podatki” 2007, nr 3, s. 16 i n.

81 Tak K. Bieńkowska [w:] E. Matyszewska, Fiskus ujawnia dane podatników, „Gazeta Prawna” z dnia 20 grudnia 2006 r., nr 247, s. 2.

82 Tak J. Kanicka [w:] E. Matyszewska, Fiskus ujawnia dane podatników, „Gazeta Prawna” z dnia 20 grudnia 2006 r., nr 247, s. 2.

83 R. Mastalski, Komentarz do art. 293 o.p..., s. 1641-1642; A. Biegalski, M. Kucewicz, Prawo do prywatności a system wymiany informacji w sprawach podatkowych (cz. III), „Prawo i Podatki” 2008, nr 8-9, s. 17-22/17-22; wyrok WSA w Gliwicach z dnia 11 czerwca 2019 r., III SA/Gl 423/19, CBOSA.

84 R. Mastalski, Komentarz do art. 293 o.p..., s. 1641. 
prywatności wraz z ochroną danych osobowych ${ }^{85}$ (art. 47 i art. 51 Konstytucji $)^{86}$. Mimo, że w przepisach Ordynacji podatkowej prawodawca poświęcił tajemnicy skarbowej oddzielny VII dział, to jednak niedoprecyzowanie jej istoty sprawia, że w znacznej części niespójne regulacje rodzą wątpliwości interpretacyjne ${ }^{87}$. Tym samym granice tajemnicy skarbowej jako szczególnego rodzaju tajemnicy państwowej (służbowej) muszą być zakreślone szeroko ${ }^{88}$, ponieważ $\mathrm{z}$ opodatkowaniem związane są m.in. zjawiska gospodarcze wraz z indywidualnymi przejawami życia jednostki, co wymaga ścisłego przestrzegania zawodowej dyskrecji dotyczącej wszelkich informacji, jakie pozyskiwane są dla potrzeb stosowania prawa podatkowego ${ }^{89}$.

W powyższym kontekście art. 299b o.p. stanowi bez wątpienia „osłabienie tajemnicy skarbowej, która w przeświadczeniu podatników i ocen formułowanych w literaturze już dawno przestała być tajemnicą chronioną skutecznie przez prawo"90. Trafne jest więc sformułowane przez H. Dzwonkowskiego pytanie brzmiące: „czy tak «wrażliwy» dla obu stron stosunku prawnopodatkowego przepis należało konstruować z wykorzystaniem klauzul generalnych, które z założenia generują niejasności interpretacyjne?”91. Warto też zaznaczyć, że „rozwiązanie legislacyjne” z art. 299b o.p., sformułowane przy użyciu klauzul generalnych,

85 „Ujawnienie informacji (danych) objętych tajemnicą skarbową w zgodzie z obowiązującym porządkiem prawnym wyłącza bezprawność naruszenia dobra osobistego" J. Orłowski, O. Nieczepa, Tajemnica skarbowa a ochrona dóbr osobistych, „Studia Prawnoustrojowe" 2020, nr 47, s. 204.

86 Wyrok WSA w Gdańsku z dnia 29 lipca 2015 r., I SA/Gd 651/15, CBOSA; wyrok NSA z dnia 1 kwietnia 2010 r., II FSK 1935/08, CBOSA; wyrok WSA w Krakowie z dnia 23 lipca 2008 r., I SA/Kr 1397/07, CBOSA; M. Niezgódka-Medek, Komentarz do art. 293 o.p. [w:] S. Babiarz, B. Dauter, R. Hauser, A. Kabat, M. NiezgódkaMedek, J. Rudowski, Ordynacja podatkowa. Komentarz, LEX/el. 2019.

87 W. Stachurski, Komentarz do art. 293 o.p..., LEX/el. 2020; A. Leszczyńska, Prawo podatnika do ochrony danych osobowych w świetle kompetencji organu podatkowego do ujawnienia tajemnicy skarbowej, „Kwartalnik Prawa Podatkowego” 2008, nr 1, s. $115-123$.

88 Z. Ofiarski, Prawo podatkowe, LEX/el. 2006.

89 Wyrok WSA w Warszawie z dnia 7 lipca 2011 r., III SA/Wa 2335/10, CBOSA.

90 C. Kosikowski, Komentarz do art. 299 b o.p..., LEX/el. 2013.

91 H. Dzwonkowski, Komentarz do art. 299b o.p. [w:] H. Dzwonkowski (red.), Ordynacja podatkowa. Komentarz, Legalis/el. 2008. 
często o bardzo trudnym do określenia obszarze znaczeniowym ${ }^{92}$, sprawia dylematy interpretacyjne ${ }^{93}$. W efekcie Szef Krajowej Administracji Skarbowej uzyskał w ramach tzw. luzu decyzyjnego nadmierną swobodę ujawniania zakresu podmiotowego i przedmiotowego tajemnicy skarbowej, których ochronę gwarantują przepisy (tzw. wzorce konstytucyjne) artykułów 47 i 51 Konstytucji RP ${ }^{94}$.

In minus należy ocenić brak w kręgu podmiotów, które mogą wystąpić w trybie art. 299b o.p. do Szefa Krajowej Administracji Skarbowej o ujawnienie określonych informacji stanowiących tajemnicę skarbową posłów i senatorów. Taka regulacja uniemożliwia bez wątpienia klasyczne wykonywanie funkcji kontrolnych parlamentu, co pośrednio prowadzi do naruszenia przysługującego obywatelom prawa do informacji o działaniach administracji rządowej oraz do kształtowania negatywnego wizerunku i podważania wiarygodności organów podatkowych w ocenie społeczeństwa. Dobitnym tego przykładem jest relacjonowany przez media kazus byłego Ministra Finansów, a wcześniej Szefa Krajowej Administracji Skarbowej, związany z wątpliwościami odnośnie prawidłowego rozliczania uzyskiwanych przez niego dochodów (przychodów) ${ }^{95}$. Niestety, organy podatkowe w odpowiedzi na publikacje prasowe (telewizyjne), których wydźwięk był bez wątpienia negatywny dla całego „aparatu finansowego”, nie wykorzystały art. 299b o.p. (sic!). Ale z drugiej strony, czy w dobie permanentnego procesu upolityczniania legislacji ${ }^{96}$ poprzez

92 Por. P. Pietrasz, Komentarz do art. 34 u.k.s..., s. 412.

93 Por. M. Kalinowski, Opinia o projekcie ustawy o zmianie ustawy o kontroli skarbowej oraz o zmianie niektórych innych ustaw (druk sejmowy nr 683) z dnia 5 lipca 2006 r., http://orka.sejm.gov.pl/WydBAS.nsf/0/87DA9D44CCEE40D3C125724500349923/\$fi le/O2006.pdf.

94 Tamże.

95 Zapytanie poselskie nr 9925 z dnia 27 września 2019 r. do Ministra Finansów w sprawie emisji reportażu na temat Pana Mariana Banasia w programie Superwizjer, http://www.sejm.gov.pl/Sejm8.nsf/interpelacja.xsp?typ=ZAP\&nr=9925.

96 Zob. T. Biernat, Między polityka a prawem. Problem „upolitycznienia” tworzenia prawa, przegląd prawa i administracji, „Przegląd Prawa i Administracji” 2017, nr 110, s. 115 i n. 
większość parlamentarną ${ }^{97}$, destrukcji, a może trafniej agonii służby cywilnej, znajdzie się tak odważny monokratyczny organ podatkowy, który wystąpił z wnioskiem w obronie dobrego imienia całej formacji związanej z poborem, wymiarem i egzekucją danin publicznoprawnych? Tak postawione pytanie skłania autora do konstatacji, że „ulepszać państwo mogą ludzie uwolnieni od egoizmu, egocentryzmu, nieżyczliwości i cwaniactwa oraz hochsztaplerstwa, odpowiednio wykształceni i posiadający zdolność zastosowywania osiągnięć nauki i cywilizacji, bez instrumentalnego naginania ich osiągnięć - świadomie lub nieświadomie - w praktycznym działaniu. Nadto, koniecznie potrzebni są ludzie posiadający cechy pokory myślowej i intelektualnej, szacunek do innych ludzi i do prawdy, a nie hermetycznie zamknięte umysły"98. W tym kontekście wciąż aktualne jest spostrzeżenie J. Szpotańskiego, że „najbardziej zaś w tym wszystkim wścieka, że właściwego brak człowieka (...)”99.

Podsumowując powyższe rozważania, należy dostrzec, że Minister Finansów już w piśmie z dnia 23 stycznia 2007 r. zapewniał parlamentarzystów, że wnioski o wyrażenie zgody na ujawnienie tajemnicy skarbowej złożone na podstawie art. 299b § 1-3 o.p. będą rozpatrywane z największą starannością i rozwagą, m.in. poprzez monitorowanie sposobu udostępnienia i wykorzystania przez organy podatkowe informacji objętych tajemnicą skarbową ${ }^{100}$. Niestety, z uzyskanych w trybie dostępu do informacji publicznej danych na dzień 7 września 2020 r. bezsprzecznie wynika, że „przed wejściem w życie ustawy z dnia 16 listopada 2016 r.

97 Szerzej W. Łączkowski, Wymiar sprawiedliwości a stosowanie prawa [w:] A. Dębiński, A. Grześkowiak, K. Wiak (red.), Ius et lex. Księga pamiq̨tkowa ku czci prof. Adama Strzembosza, Lublin 2002, s. 49 i n.; I. Nowak, Funkcjonariusze..., s. 43.

98 B. Jastrzębski, Ustrojowe zasady demokratycznego państwa prawa (jako gwarancje ochrony praw obywatelskich) [w:] E. Ura (red.), Prawne gwarancje ochrony praw jednostki wobec działań administracji publicznej, Rzeszów 2002, s. 201 za E. Ura, S. Pieprzny, Reforma administracji celno-skarbowej przyczynq wygaśnięcia stosunków zatrudnienia z mocy prawa pracowników i funkcjonariuszy tej administracji [w:] J. Strzelecki (red.), Przemiany cywilizacyjne a funkcjonowanie administracji publicznej. Księga jubileuszowa dedykowana Profesorowi Bronisławowi Jastrzębskiemu w dziewięćdziesiątq rocznicę urodzin, Płock 2017, s. 181.

99 J. Szpotański, Gnom. Caryca. Szmaciak, Łomianki 2014, s. 192.

100 Pismo Ministra Finansów z dnia 23 stycznia 2007 r., http://orka2.sejm.gov.pl/IZ5.nsf/main/5F739689. 
o Krajowej Administracji Skarbowej przedmiotowe dane nie były gromadzone”101. Innymi słowy, od wejścia w życie przepisu art. 299b o.p., tj. od 1 stycznia 2007 r., do 1 marca 2017 r. Minister Finansów nie dysponuje żadnymi danymi wskazującymi, ile było wyrażonych zgód na ujawnienie określonych informacji stanowiących tajemnicę skarbową ${ }^{102}$.

\section{Bibliografia:}

Banasiak S., Oraczewska D., Tajemnica skarbowa a tajemnica bankowa, ISPMiW, Warszawa 1998.

Benduch D., Tajemnica skarbowa, „Monitor Podatkowy” 2014, nr 15, Legalis/el.

Biegalski A., Kucewicz M., Prawo do prywatności a system wymiany informacji w sprawach podatkowych (cz. I-II), „Prawo i Podatki” 2008, nr 8-9, s. $17-22 / 17-22$.

Biernat T., Między politykq a prawem. Problem „upolitycznienia” tworzenia prawa, przegląd prawa i administracji, „Przegląd Prawa i Administracji” 2017, nr 110, s. 115-132.

Borszowski P., Określenia nieostre i klauzule generalne w prawie podatkowy, Wolters Kluwer, Warszawa 2017.

Brzeziński B., Opinia o rzq̨dowym projekcie ustawy o zmianie ustawy Ordynacja podatkowa oraz o zmianie niektórych innych ustaw (Druk sejmowy 731), http://orka.sejm.gov.pl/WydBAS.nsf/0/87DA9D44CCEE40D3C125724500 349923/\$file/O2006.pdf.

Brzeziński B., Kalinowski M., Masternak M., Olesińska A., Orłowski J., Ordynacja podatkowa. Komentarz, tom II, TNOiK, Toruń 2007.

Brzeziński B., Kalinowski M., Olesińska A. (red.), Ordynacja podatkowa. Komentarz praktyczny, ODDK, Gdańsk 2017.

Brzeziński B., O idei równoważenia praw i obowiq̨zków podatników oraz administracji podatkowej w projekcie nowej Ordynacji podatkowej [w:] J.M. Sa-

101 Według pisma Ministra Finansów z dnia 7 września 2020 r., nr BMI1.0123.1319.2020.

102 Natomiast w okresie od dnia 1 marca 2017 r. do 31 sierpnia 2020 r. „liczba zgód Szefa Krajowej Administracji Skarbowej, udzielonych na podstawie art. 299b Ordynacji podatkowej, na ujawnienie przez naczelników urzędów skarbowych, naczelników urzędów celno-skarbowych, dyrektorów izb administracji skarbowej, określonych informacji stanowiących tajemnicę skarbową wyniosła 5” - pismo Ministra Finansów z dnia 7 września 2020 r., nr BMI1.0123.1319.2020. 
lachna, K. Stelmaszczyk, P. Borszowski, Prawo i administracja dla regionu nr 4. Zagadnienia prawnofinansowe, PWSZ, Wałbrzych 2016.

Choduń A., Gomułowicz A., Skoczylas A.P., Klauzule generalne i zwroty niedookreślone w prawie podatkowym i administracyjnym. Wybrane zagadnienia teoretyczne i orzecznicze, LEX/el 2013.

Chróścielewski W., Nykiel W., Postępowanie podatkowe w świetle Ordynacji podatkowej, C.H. Beck, Warszawa 2000.

Dworniak K., Ordynacja podatkowa. Komentarz, Legalis/el. 2003.

Dzwonkowski H., Komentarz do art. 299 b.p. [w:] H. Dzwonkowski (red.), Ordynacja podatkowa. Komentarz, Legalis/el. 2008.

Etel L. (red.), Nowa Ordynacja podatkowa. Z prac Komisji Kodyfikacyjnej Ogólnego Prawa Podatkowego, Temida 2, Białystok 2017.

Gliniecka J., Tajemnica finansowa. Aspekty aksjologiczne, normatywne i funkcjonalne, Branta, Bydgoszcz-Gdańsk 2007.

Gliniecka J., Wyjątek od zasady tajemnicy skarbowej czy zaprzeczenie jej istoty?, „Prawo i Podatki” 2007, nr 3, 16-21.

Gliniecka J., Odpowiedzialność prawna zwiqzzana z naruszeniem obowiq̨zku zachowania tajemnicy finansowej, „Gdańskie Studia Prawnicze” 2009, t. 21, s. $167-186$.

Gliniecka J., Komentarz do art. 293 o.p. [w:] Dzwonkowski H. (red.) Ordynacja podatkowa. Komentarz, Legalis/el. 2011.

Gliniecka J., Dzwonkowski H., Kondratowska J., Komentarz do art. 293 o.p. [w:] H. Dzwonkowski (red.), Ordynacja podatkowa. Komentarz, Legalis/el. 2014.

Gomułowicz A., Małecki J., Podatki i prawo podatkowe, LexisNexis, Warszawa 2010.

Gomułowicz A., Ingerencyjny charakter prawa podatkowego [w:] J. Głuchowski (red.) Współczesne problemy prawa podatkowego. Teoria i praktyka. Księga jubileuszowa dedykowana Profesorowi Bogumiłowi Brzezińskiemu, tom. I, Wolters Kluwer, Warszawa 2019.

Habrat D., Majka P., Upoważnienie inspektora kontroli skarbowej do ujawniania informacji stanowiq̨cych tajemnicę skarbowq, „Przegląd Podatkowy” 2013, nr 8, s. 36-43.

Hanusz A., Niezgoda A., Czerski P., Dochody jednostek samorzq̨du terytorialnego, Wolters Kluwer, Warszawa 2009.

Janik E., Tajemnica skarbowa - głos w dyskusji [w:] P. Malinowski, T. Nowak, A. Sędkowska (red.), Kontrola podatkowa, skarbowa i celna, LEX/el. 2013. 
Jastrzębski B., Ustrojowe zasady demokratycznego państwa prawa (jako gwarancje ochrony praw obywatelskich) [w:] E. Ura (red.), Prawne gwarancje ochrony praw jednostki wobec działań administracji publicznej, Mitel, Rzeszów 2002.

Jezierski J., Tajemnica skarbowa w Ordynacji podatkowej [w:] Księga pamiq̨tkowa ku czci docenta Eligiusza Drgasa, TNOiK, Toruń 1998.

Kalinowski M., Opinia o projekcie ustawy o zmianie ustawy o kontroli skarbowej oraz o zmianie niektórych innych ustaw (druk sejmowy nr 683) z dnia 5 lipca 2006 r., http://orka.sejm.gov.pl/WydBAS.nsf/0/87DA9D44CCEE40D3C 125724500349923/\$file/O2006.pdf.

Kondratowska-Muszyńska J., Komentarz do art. 294 o.p. [w:] H. Dzwonkowski (red.), Ordynacja podatkowa. Komentarz, Legalis/el. 2020.

Kosikowski C., Komentarz do art. 294 o.p. [w:] H. Dzwonkowski, A. Huchla, C. Kosikowski, Ordynacja podatkowa. Komentarz, LEX/el. 2003.

Kosikowski C., Komentarz do art. 293 o.p. [w:] J. Brolik, R. Dowgier, L. Etel, C. Kosikowski, P. Pietrasz, M. Popławski, S. Presnarowicz, W. Stachurski, Ordynacja podatkowa. Komentarz, LEX/el. 2013.

Kośmider M., Gromadzenie przez organy podatkowe informacji objętych tajemnicq bankowq a prawo do prywatności, „Kwartalnik Prawa Podatkowego” 2002, nr 1, s. 45-62.

Kośmider M., Tajemnica skarbowa a informacje pochodzq̨e z banków i innych instytucji finansowych, „Kwartalnik Prawa Podatkowego” 2002, nr 2, s. 101-112.

Krawczyk P., Czy tajemnica skarbowa jest potrzebna? [w:] R. Dowgier (red.) Ordynacja podatkowa. Wokół nowelizacji, Temida 2, Białystok 2009.

Kulicki J., Kontrola skarbowa. Komentarz (do art. 34), LEX/el. 2013.

Leszczyńska A., Prawo podatnika do ochrony danych osobowych w świetle kompetencji organu podatkowego do ujawnienia tajemnicy skarbowej, „Kwartalnik Prawa Podatkowego" 2008, nr 1, s. 115-123.

Łączkowski W., Wymiar sprawiedliwości a stosowanie prawa [w:] A. Dębiński, A. Grześkowiak, K. Wiak (red.), Ius et lex. Księga pamiq̨tkowa ku czci prof. Adama Strzembosza, KUL, Lublin 2002.

Marek R., Tajemnica skarbowa a dostęp do informacji publicznej, Legalis/el.

Mastalski R., Komentarz do art. 293 o.p. [w:] B. Adamiak, J. Borkowski, P. Borszowski, R. Mastalski, J. Zubrzycki, Ordynacja podatkowa. Komentarz, Unimex, Wrocław 2017. 
Mastalski R., Komentarz do art. 299 b o.p. [w:] B. Adamiak, J. Borkowski, P. Borszowski, R. Mastalski, J. Zubrzycki, Ordynacja podatkowa. Komentarz, Unimex, Wrocław 2017.

Matyszewska E., Fiskus ujawnia dane podatników, „Gazeta Prawna” z dnia 20 grudnia 2006 r., nr 247, s. 2.

Melezini A., Tajemnica skarbowa [w:] A. Melezini, D. Zalewski, Kontrola podatkowa przedsiębiorców, LEX/el. 2012.

Melezini A., Prawne instrumenty zapobiegania i zwalczania korupcji przez kontrolę skarbowq, LEX/el. 2012.

Melezini A., Komentarz do art. 54 u.K.A.S. [w:] K. Teszner (red.) Krajowa Administracja Skarbowa. Komentarz, LEX/el. 2018.

Münnich M., Nieostre zwroty ocenne w polskim prawie podatkowym, KUL, Lublin 2017.

Niezgódka-Medek M., Komentarz do art. 293 o.p. [w:] S. Babiarz, B. Dauter, R. Hauser, A. Kabat, M. Niezgódka-Medek, J. Rudowski, Ordynacja podatkowa. Komentarz, LEX/el. 2019.

Nita A., Wymuszona współpraca podatnika w procesie wymiaru podatku, „Państwo i Prawo” 2013, nr 12, s. 31-45.

Nita A., Niewładcze metody oddziaływania na treść powinności podatkowych [w:] I. Niżnik-Dobosz (red.), Zastosowanie idei public governance w prawie administracyjnym, Difin, Warszawa 2014.

Nowak I., Prawo podatkowe jako prawo publiczne w świetle jego odrębności jako gałęzi prawa - wybrane zagadnienia [w:] P. Ruczkowski (red.), Prawo - społeczeństwo - jednostka. Człowiek - najlepsza inwestycja, WSEiP, Kielce 2010.

Nowak I., Nowak A., Jawność postępowania podatkowego, „Rozprawy z Zakresu Nauk Prawnych” 2012, nr 3, s. 161-176.

Nowak I., Ciężar dowodzenia w postępowaniu podatkowym - podstawowe problemy [w:] B. Kucia-Guściora, M. Münnich, A. Zdunek, R. Zieliński (red.), Stanowienie i stosowanie prawa podatkowego w Polsce. Ocena i kierunki zmian, KUL, Lublin 2016.

Nowak I., Ledzion I., Udostępnianie akt sprawy podatkowej, cz. I-II, „Przegląd Podatków Lokalnych i Finansów Samorządowy” 2017, nr 4-5, s. 17-21/17-23.

Nowak I., Wyłqzczenie samorzqdowych organów podatkowych od załatwiania spraw w postępowaniu podatkowym, „Przegląd Podatków Lokalnych i Finansów Samorządowych” 2017, nr 6, s. 20-26. 
Nowak I., Wyłqczenie pracownika samorzq̨dowego organu podatkowego od udziału w postępowaniu podatkowym - zagadnienia ogólne, „Przegląd Podatków Lokalnych i Finansów Samorządowych” 2017, nr 8, s. 25-28.

Nowak I., Zwiq̨zanie organu podatkowego wydanq i doręczonq decyzjq, „Przegląd Podatków Lokalnych i Finansów Samorządowych” 2018, nr 10, s. 23-28.

Nowak I., Funkcjonariusze celni w strukturze Krajowej Administracji Skarbowej - uwagi wybrane, „Kwartalnik Prawa Podatkowego” 2019, nr 2, s. 37-56.

Nowak I., National Revenue Administration - current organisational and financial problems, „Prawo Budżetowe Państwa i Samorządu 2020”, nr 2, s. 37-65.

Nowak I., Krajowa Administracja Skarbowa w liczbach, „Kazus Podatkowy” 2020, nr 4, s. 24-25.

Nowak I., Zasada jawności w jurysdykcyjnym postępowaniu podatkowym na tle inkwizycyjnego stosunku podatkowoprawnego, „Przegląd Podatków Lokalnych i Finansów Samorządowych” 2020, nr 7, s. 25-31.

Nykiel W., O potrzebie równowagi między uprawnieniami i obowiq̨zami podatnika oraz organów podatkowych, „Prawo i Podatki” 2005, nr 12, s. 25-28.

Ofiarski Z., Prawo podatkowe, LEX/el. 2006.

Orłowski J., Nieczepa O., Tajemnica skarbowa a ochrona dóbr osobistych, „Studia Prawnoustrojowe” 2020, nr 47, s. 191-207.

Pietrasz P., Komentarz do art. 43 u.k.s. [w:] P. Pietrasz, W. Stachurski, Ustawa o kontroli skarbowej. Komentarz, Presscom, Wrocław 2011.

Pelewicz G., Komentarz do art. 34 u.k.s. [w:] K. Kandut, A. Sędkowska (red.), Ustawa o kontroli skarbowej. Komentarz, LEX/el. 2014.

Serwacki J., Tajemnica skarbowa [w:] M. Grzybowski (red.), Państwo demokratyczne, prawne i socjalne. Księga jubileuszowa dedykowana Profesorowi Zbigniewowi Antoniemu Maciagowi, AFM, Kraków 2014.

Sołoniewicz K., Tajemnica skarbowa [w:] A. Mariański (red.), Ordynacja podatkowa 2017. Poradnik dla praktyków, Legalis/el. 2017.

Stachurski W., Komentarz do art. 293 o.p. [w:] L. Etel (red.), Ordynacja podatkowa. Komentarz aktualizowany, LEX/el. 2020.

Szubiakowski M., Problemy prawnej regulacji tajemnicy skarbowej, „Zeszyty Naukowe Sądownictwa Administracyjnego” 2014, nr 4, s. 9-18.

Szustakiewicz P., Dostęp do informacji publicznej, Legalis/el. 2019.

Szpotański J., Gnom. Caryca. Szmaciak, LTW, Łomianki 2014.

Ura E., Pieprzny S., Reforma administracji celno-skarbowej przyczynq wygaśnięcia stosunków zatrudnienia z mocy prawa pracowników i funkcjonariuszy tej administracji [w:] J. Strzelecki (red.), Przemiany cywilizacyjne a funkcjo- 
nowanie administracji publicznej. Księga jubileuszowa dedykowana Profesorowi Bronisławowi Jastrzębskiemu w dziewięćdziesiąta rocznicę urodzin, WN Novum, Płock 2017.

Zalewski D., Melezini A., Ustawa o kontroli skarbowej. Komentarz (do art. 34), Legalis/el. 2012.

Zalewski D., Naruszenie tajemnicy skarbowej a legalność postępowania podatkowego, „Monitor Podatkowy” 2019, nr 11, Legalis/el. 